\title{
Prevalence of Gastrointestinal Parasites of Hunting Dogs in Maiduguri, Borno state, Nigeria
}

\author{
F.B Mustapha ${ }^{1}$, S.B Balami ${ }^{1}$, S.A Malgwi ${ }^{2}$, S.G Adamu ${ }^{1}$ and Y.Wakil ${ }^{3}$ \\ ${ }^{I}$ Department of Veterinary Public Health and Preventive Medicine, Faculty of Veterinary Medicine, University \\ of Maiduguri, P.M.B. 1069, Maiduguri, Borno State, Nigeria. \\ ${ }^{2}$ Department of Veterinary Microbiology and Parasitology, Faculty of Veterinary Medicine, University of \\ Maiduguri, P.M.B. 1069, Maiduguri, Borno State, Nigeria. \\ ${ }^{3}$ Department of Veterinary Medicine, Faculty of Veterinary Medicine, University of Maiduguri, P.M.B. 1069, \\ Maiduguri, Borno State, Nigeria.
}

\begin{abstract}
This study was geared towards investigating the prevalence of gastrointestinal parasites of hunting dogs in Maiduguri, Borno state, Nigeria. A total of 250 feacal samples were collected per rectum. The parasites were determined using formol ether and floatation concentration methods. An overall prevalence of $38 \%$ for gastrointestinal infection was recorded. The prevalence was higher in young 39(48.1\%) than adults 56(33.1\%). The prevalence in relation to sex shows that males had a higher prevalence $42(40.8 \%)$ than the females $56(33.1 \%)$. The prevalence of infection according to sex and age was statistically not significant $(p<0.05)$. This study provides evidence that gastrointestinal parasitic infection are prevalent in hunting dogs in the study area with some of the infections being zoonotic a public health risk to man.
\end{abstract}

Keywords: Borno state, Gastrointestinal, Hunting dogs, Nigeria, Prevalence.

\section{Introduction}

Dogs are the most successful canids adapted to human habitation worldwide [1]. Recent genetic fossil and DNA evidence shows that dogs were early as 100,000 years ago [2]. The intelligence of these animals has been explain by man, and this has made dogs useful to man for various activities, which includes hunting, retrieving, herding, rescue operations, tracking and guidance [3]. Dogs are also considered as loyal friends and compatriots to man [4]. Despite the substantial benefits derived from keeping dog. Dogs also act as reservoir for a large number of parasitic zoonoses such as toxocariosis and ancylostomosis especially in developing countries and communities that are socio-economically disadvantaged [5].

The common council signs and symptoms of gastrointestinal parasite infection in dogs include nausea, vomiting, fever, weightloss, anaemia, dull hair coat and sudden death [6]. With increasing number of security and hunting dogs in Maiduguri there is more contact between dogs and people and exposing humans to zoonotic parasites. The transmission of these parasites could be by direct contact with dog and indirectly with the dog excretions and secretions [7]. Despite the extensive work carried on intestinal parasites of dogs in various parts of the country especially in Maiduguri, there is paucity of information on the prevalence of gastrointestinal parasites in hunting dogs in Maiduguri, Borno state, Nigeria. Thus this study was undertaken in the study area.

\section{Study Area}

\section{Materials And Methods}

This study was carried out in Maiduguri, the capital and largest urban city of Borno state, in the north eastern part of Nigeria. It is cosmopolitan in nature, situated at an elevation of 354 meters above sea level, located between latitudes $11^{\circ}$ and $14^{\circ} \mathrm{N}$ and longitudes $10^{\circ}$ and $14^{\circ} \mathrm{E}$, within the conventional Sahel zone and has a total land mass of 50,778 square kilometers [8]. It has a population density 1,738 people per square kilometers, and a total population of 521,492[9]. It is bordered by the Republic of Niger to the north, Cameroon republic to the east and to the northeast by Chad Republic, within the country its neighbouring states are Adamawa to the south, Yobe to the west and Gombe to the southwest. The temperature ranges from $35-40^{\circ} \mathrm{C}$ for the most parts of the year with 2 distinct seasons, a rainy season with a mean annual rainfall of $647 \mathrm{~mm}$ from July to October and a prolonged dry season for the rest of the year [10]. The state derives great economic activity from its rich livestock and fishery production [9].

\section{Sample Size Estimation.}

The sample size was determined using formular of thrustfield [11]. Using a previous prevalence of $13.8 \%$ [12] and the calculated sample size was 183 samples for more precision 250 feacal samples were collected from hunting dogs. 
Prevalence Of Gastrointestinal Parasites Of Hunting Dogs In Maiduguri, Borno State, Nigeria.

\section{Sample Collection}

Feacal samples were collected from the rectum of dogs using protective disposable gloves at various locations within Maiduguri between May to July 2016. The samples were put into universal bottles carefully labelled indicating sex and age which were transported in an ice pack to the Veterinary Microbiology and Parasitology laboratory of the faculty of veterinary medicine, university of Maiduguri for processing. Prior to feacal collection, animals were identified, restraint and the perineum thoroughly prepared by cleaning with water to prevent contamination. Simple random sampling technique was employed.

\section{Sample Processing and Feacal Examination}

Feacal samples were processed and screened using two methods, the formol ether concentration and the sodium chloride flotation technique [13], [14].

\section{Microscope Examination}

Identification of parasite eggs was done in accordance to keys of Soulsby [13].

\section{Statistical Analysis}

All data generated during sample collection and laboratory examination of samples were recorded. Prevalence was calculated as $\mathrm{p}=\mathrm{d} / \mathrm{n}(\%)$, where $\mathrm{p}=$ prevalence, $\mathrm{d}=$ number infected and $\mathrm{n}=$ number examined [11]. Chi-square was used to compare the prevalence of intestinal parasites between young and adults as well as male and female using Graphad Instat [15].

\section{Results}

The prevalence of intestinal parasites of hunting dogs according to sex in Maiduguri, Borno state, Nigeria is presented in table 1 . Out of the total 250 feacal samples examined, $95(38 \%)$ were positive, however out of the 250 feacal samples 103 were males while 147 were females. A higher prevalence rate was recorded in males $42(40.8 \%)$ compared to females $53(36.1 \%)$. There was no statistical variation in the prevalence rate between sexes $(\mathrm{p}>0.05)$.

Table 2 shows the prevalence of intestinal parasites in hunting dogs according to age in Maiduguri, Borno state, Nigeria. Out of the 250 feacal samples examples examined, 81 were young while 169 were adults. A higher prevalence was recorded in young $39(48.1 \%)$ as to adults $56(33.1 \%)$. There was no statistical variation in the prevalence rate between sexes $(\mathrm{p}>0.05)$.

Table 3 shows the prevalence of various intestinal parasites of hunting dogs in Maiduguri, Borno state. Out the 95 positive samples, Ancylostoma spp, Toxocara spp, Diphylidium spp, Isospora spp and Taenia spp were detected recording prevalence rate of 52(54.8\%), 14(14.7\%), 12(12.6\%), 10(10.5\%) and 7(7.3\%) repectively with Ancylostoma recording the highest prevalence rate.

\section{Discussion}

This study revealed an overall prevalence of $38 \%$, which is lower compared to the report of Umoh and Asake, [16] who reported a prevalence of $83 \%$ for Zaria area, so also are Olufemi and Babode [17] and Mahmud et al. [18] who reported prevalence of $86.9 \%$ and $72.5 \%$ in Calabar and Sokoto state, Nigeria. However it is closely related to the report of Kamani et al. [19] who reported a prevalence of 37\% in Vom, Nigeria.

The intestinal parasites identified in the study include Ancylostoma spp, Toxocara spp, Diphylidium spp., Isospora spp., and Taenia spp. The most frequently observed intestinal parasites in the study was Ancylostoma spp 52 (54.8\%) followed by Toxocara spp, Diphylidum spp, Isospora spp and Taenia spp with 14 (14.7), 12 (12.6) $10(10.5 \%)$ and 7 (7.3\%) respectively. The most commonly encountered parasites in this study was Ancylostoma spp (54.8\%), which is in agreement with other research findings in Nigeria [20], [21], and [5] and other parts of the world [22], [23] and [24]. Difference in frequency of gastrointestinal helminth infection between countries is possible is possible due to differences in climatic factors required for the biology of the parasites, veterinary facilities and public awareness to take care of dogs. [25], [26].

A higher prevalence rate was observed in males $(40.8 \%)$ compared to females $(36.1 \%)$ in the study, this could be attributed to the fact that male dogs tend to travel long distances to search for females partners during breeding season. So also was higher prevalence in puppies $(48.1 \%)$ than adults $(33.1 \%)$. The high prevalence observed for puppies was in accordance with the findings by other workers. [27], [28], [7] and [29]. This could be due to the fact that most adults are carriers shedding infective eggs after acquiring immunity from previous exposure. There is also possibility of transplacental or transcolostral transmission of helminthes (Soulsby, 1982). Most helminthes diagnosed in this study (Ancylostoma spp, Toxocara spp and Diphylidium spp) are potential zoonoses with severe consequences in man especially children [30]. 
Prevalence Of Gastrointestinal Parasites Of Hunting Dogs In Maiduguri, Borno State, Nigeria.

\section{Conclusion}

The intestinal parasites detected in the study include; Ancylostoma spp, Toxocara spp, Diphylidum spp., Isospora spp., and Taenia spp with Ancylostoma spp having the highest prevalence rate. Infection rate was higher in males than females so also was it higher in young than adult dogs.

\section{Acknowledgements}

The authors are grateful to the staff of the Department of Veterinary Microbiology and Parasitology laboratory of the University of Maiduguri for their technical support and the cooperation of the hunters association in Maiduguri during the study.

\section{References}

[1]. Tannen D. (2004) Talking the dog: framing pets as interactional resources in family discourse. Res. Lang. Soc. Interac., 37, 399420 .

[2]. Lindblad-Toh K., Wade C.M., Mikkelsen T.S. (2005). Genome sequence, comparative analysis and haplotype structure of the domestic dog. Nature, 438, 803-819

[3]. Jane E. ( 1996). Collins Gem Dogs photoguide $1^{\text {st }}$ edition pg 5-6.

[4]. Romero C, Mendoza G.E, Pinedar M.A, Nava N., Bautista L.G and Heredia R. (2015). Prevalence of Intestinal parasites with zoonotic potential in canids Mexico. Acta scientiae veterinariae. 43.1307

[5]. Kutdang, E.T. Bukbuk, D.N. and Ajayi J.A. (2010). The Prevalence of intestinal helminths of Dogs (Canis familaris) in Jos, Plateau State Nigeria. Researcher 2(8): 51-56.

[6]. Asano, K; Suzuki, K and Asano, R. (2011). Prevalence of intestinal parasites in dogs in National Capital Region of Japan. Journal of Animal and veterinary Advances, 10(20):2666-2668

[7]. Lorenzini G., Tasca T. and De Carli G.A.(2007). Prevalence of intestinal parasites in dogs and cats under Veterinary care in Porto Ategre, Rio Grande do Sul, Brazil. Brazil journal of Veterinary Research animal Science, volume 44: 137-145.

[8]. $\quad$ Borno state Ministry of Lland and Survey (BMLS), (2007). Annual report pp 15- 18.

[9]. National Population Commision, (2006). Nigerian National Population census Report. 109pp

[10]. Lake chad research institute (LCRI), (2007). Annual weather report.30pp.

[11]. Thrustfield M. Ed (2005). Veterinary Epidemiology. $3^{\text {rd }}$ edition. Oxford UK. Blackwell science.

[12]. Adamu, N.B., Adamu,Y.A., Salisu, L. (2012) Prevalence of ecto-, endo- and haemoparasites in slaughtered dogs in Maiduguri, Nigeria. Revue Méd. Vét. 163, 4, 178-182

[13]. Soulsby E.J.L.(1982). Helminths, arthropods and protozoa of domesticated animals $7^{\text {th }}$ edition. Bailliere Tindall, London pg $276-$ 284

[14]. Graphad ${ }^{\mathrm{R}}$ Instat (2002). Version 3.00 for windows. Graphad software San Diego CA, USA. www.Graphad.com

[15]. Umoh, 1.U., Asake, T.T.(1982). Prevalence of parasites ova and cysts in dog faeces deposited on streets of staff quarters of Ahmadu Bello University, Zaria, Nigeria. Niger. Vet. J. 11, 2.

[16]. Olufemi, B.E., Bobade, P.A.(1979). Prevalence of gastrointestinal helminth parasites of dogs in Ibadan, Nigeria. Nigerian Vet. J. 8, 68-70.

[17]. Mahmud, A., Magaji, A.A., Yakubu, Y., Salihu, M.D., Lawal, M.D., Mahmud, U., Suleiman,N., Danmaigoro, A. (2012). Prevalence of intestinal parasites of dogs slaughtered at Mami market area, Sokoto, Nigeria. Scientific Journal of Animal Science. 1(3) 126-130.

[18]. Kamani, J., Weka, P.R., Gbisi, S.D (2011), Parasitic Causes of Anaemia in Dogs in Vom, Nigeria. IJAVMS 5(3): 283-289.

[19]. Ugochukwu, E.I., Ejimadu, K.N.(1985). Studies on the prevalence of gastrointestinal helminths of dogs in Calabar,Nigeria. Inter. J. Zoonos., 21, $214-218$.

[20]. Onyenwe, I.W., Ikpegbu, E.O.(2004). Prevalence of gastrointestinal helminth parasites (GIHP) of dogs presented at the University of Nigeria Veterinary Teaching Hospital (UNVTH) between 1994 and 2002, Nigerian Vet. J. 25(1), 21 - 25.

[21]. Jordan, H.F., Mullins, S.T., Stebbins, M.E.(1993). Endoparasitism in dogs: 21, 583 cases (1981- 1990). J. Ameri. Vet. Med. Associ. 203(4), $547-549$

[22]. Blagburn, B.L.(2001). Prevalence of canine and feline parasites in the United States of America. Compendium on continuing education for the practicing veterinarian, 23(6A), $5-10$

[23]. Ramirez - Barrios, R.A., Barboza - Mena, G., Munoz, L, Angulo-cubillan, F., Henandez, E., Gonzalez, F., Escalona, F.(2004). Prevalence of intestinal parasites in dogs under veterinary care in Maracaibo, Venezuela. Vet. Parasitol. 121, 11- 20

[24]. Ugomoiko U.S, Ariza L., Heukelbach J. (2008); parasites of importance for human health in Nigerian dogs: high prevalence and limited knowledge of pet owners. BMC Vet. Res. (4) 49

[25]. Yacob H.T, Ayelet T., Fikru R., Basu A.K. (2007). Gastrointestinal namatodes in dogs from zeit, Ethiopia vet parasitol. 148, 14448.

[26]. Onyenwe, I.W., Ikpegbu, E.O.(2004). Prevalence of gastrointestinal helminth parasites (GIHP) of dogs presented at the University of Nigeria Veterinary Teaching Hospital (UNVTH) between 1994 and 2002, Nigerian Vet. J. 25(1), 21- 25

[27]. Sarger H. Steiner Moret C., Multer N. Staubli D. Esposito M. Schares G. Hassig M., Stark K. and Gottsterin. B.(2006b). Incidence of Neospora caninum and other intestinal protozoam parasites in populations of Swiss dogs Veterinary Parasitology 139, 84-92.

[28]. Martinez-Moreno F.J. , Hernandez S., Lopez -Coobos E., Becerra C., Acosta I., Martinez-Mareio A.(2007). Estimation of canine intestinal parasites in Cordoba (spain) and their risk to public health. Veterinary Parasitology 143, 7 - 13

[29]. Adejoke O.N (2005). prevalence of intestinal parasite of dog in Lagos, Nigeria Pakistan journal of scientific and Industrial research 48(4); 279-283

Table 1: Prevalence of Gastrointestinal Parasites of Hunting Dogs according to Sex in Maiduguri, Borno State, Nigeria.

\begin{tabular}{|l|l|l|}
\hline Sex & No Examined & \% Number of Positive \\
\hline Male & 103 & $42(40.8)^{\mathrm{a}}$ \\
Female & 147 & $53(36.1)^{\mathrm{a}}$ \\
\hline Total & 250 & $95(38.0)$ \\
\hline
\end{tabular}

Numbers with same superscript in $3^{\text {rd }}$ column did not differ significantly $(\mathrm{P}>0.05)$ : chi-square. 
Prevalence Of Gastrointestinal Parasites Of Hunting Dogs In Maiduguri, Borno State, Nigeria.

Table 2: Prevalence of Gastrointestinal Parasites of Hunting Dogs according to Age in Maiduguri, Borno State, Nigeria.

\begin{tabular}{|l|l|l|}
\hline Age & No Examined & No of Positive (\%) \\
\hline Young (<1 year) & 81 & $39(48.1)^{\mathrm{a}}$ \\
Adult ( $>$ 1 year) & 169 & $56(33.1)^{\mathrm{a}}$ \\
\hline Total & 250 & $95(38.0)$ \\
\hline
\end{tabular}

Numbers with same superscript in $3^{\text {rd }}$ column did not differ significantly $(\mathrm{P}>0.05)$ : chi-square.

Table 3: Prevalence of Various Gastrointestinal Parasites of Hunting Dogs in Maiduguri, Borno State, Nigeria.

\begin{tabular}{|l|l|}
\hline Parasites & No. Positive(\%) \\
\hline Ancylostoma spp. & $52(54.8)$ \\
Toxocara spp. & $14(14.7)$ \\
Diphylidium spp. & $12(12.6)$ \\
Isospora spp. & $10(10.5)$ \\
Taenia spp. & $7(7.3)$ \\
\hline Total & $95(100)$ \\
\hline
\end{tabular}

